\title{
Armillaria mellea Induces a Set of Defense Genes in Grapevine Roots and One of Them Codifies a Protein with Antifungal Activity
}

\author{
Michele Perazzolli, Federica Bampi, Silvia Faccin, Mirko Moser, Federica De Luca, Anna Maria Ciccotti, \\ Riccardo Velasco, Cesare Gessler, llaria Pertot, and Claudio Moser \\ IASMA Research and Innovation Centre, Fondazione Edmund Mach, Genomics and Crop Biology Area, S. Michele a/Adige \\ 38010, Italy
}

Submitted 31 July 2009. Accepted 17 November 2009.

\begin{abstract}
Grapevine root rot, caused by Armillaria mellea, is a serious disease in some grape-growing regions. Young grapevines start to show symptoms of Armillaria root rot from the second year after inoculation, suggesting a certain degree of resistance in young roots. We used a suppression subtractive hybridization approach to study grapevine's reactions to the first stages of $A$. mellea infection. We identified 24 genes that were upregulated in the roots of the rootstock Kober 5BB 24 h after $A$. mellea challenge. Realtime reverse-transcriptase polymerase chain reaction analysis confirmed the induction of genes encoding protease inhibitors, thaumatins, glutathione S-transferase, and aminocyclopropane carboxylate oxidase, as well as phasechange related, tumor-related, and proline-rich proteins, and gene markers of the ethylene and jasmonate signaling pathway. Gene modulation was generally stronger in Kober 5BB than in Pinot Noir plants, and in vitro inoculation induced higher modulation than in greenhouse Armillaria spp. treatments. The full-length coding sequences of seven of these genes were obtained and expressed as recombinant proteins. The grapevine homologue of the Quercus spp. phase-change-related protein inhibited the growth of $A$. mellea mycelia in vitro, suggesting that this protein may play an important role in the defense response against A. mellea.
\end{abstract}

Armillaria mellea (Vahl) P. Kumm. is the causal agent of root rot in several perennial woody forest plants (Fox 2000) and crops (Cox and Scherm 2006), including grapevine (Baumgartner 2004). Grapevine root rot is an emerging disease in some important grape-growing regions, such as California (Baumgartner and Rizzo 2002), Spain (Aguín-Casal et al. 2004). and Italy (Pertot et al. 2008). A. mellea is a saproparasitic basidiomycete that can survive for a long time on dead wood and root debris in the soil in the absence of any living host (Baumgartner and Rizzo 2006). For this reason, Armil-

This article is dedicated to the memory of Federica Bampi, who unexpectedly passed away. This work was part of her graduate thesis.

Corresponding author: Claudio Moser; Telephone: +39 0461 615314; Fax: +39 0461 650956; E-mail: claudio.moser@iasma.it

Current addresses of Mirko Moser: RLP AgroScience GmBH, Cesare Gessler, Institute of Plant Science, ETH Zürich.

* The $e$-Xtra logo stands for "electronic extra" and indicates that a supplementary table is published online. laria root disease is often observed in vineyards planted on land previously occupied by forest trees (Baumgartner and Rizzo 2002) or infected vineyards (Pertot et al. 2008).

A. mellea rhizomorphs (organized mycelial structures) penetrate healthy grapevine roots by mechanical and enzymatic means (Robinson et al. 2000). Once it has penetrated a root, $A$. mellea forms a mycelial fan underneath the bark and decomposes the underlying cambium, causing the decay of the secondary xylem (Baumgartner 2004). Infected grapevines show a decline in vigor, stunted shoots, dwarfed leaves, premature change of leaf color in autumn (Pertot et al. 2008), defoliation, and reduced quantity and quality of fruits (Baumgartner and Warnock 2006). Infected plants generally die some years after infection (Baumgartner and Warnock 2006; Pertot et al. 2008).

The commonly used Vitis rootstocks are susceptible to A. mellea (Aguín-Casal et al. 2004; Baumgartner and Rizzo 2006; Prodorutti et al. 2009). A lower frequency of A. mellea infection has been demonstrated only for the Teleki $5 \mathrm{C}$ rootstock (Prodorutti et al. 2009) and the Vitis hybrid Freedom (Baumgartner and Rizzo 2006). To date, post-infection control agents have not been available and agronomic practices, such as the careful removal of inoculum (elimination of infected plants and root debris), have been used to reduce the spread of Armillaria spp. in vineyards (Fox 2003). Soil fumigants cannot completely eradicate Armillaria spp. from soil (Aguín-Casal et al. 2006). Promising results have been reported for applications of antagonistic fungi (Otieno et al. 2003; Cox and Scherm 2006), bacteria (Baumgartner and Warnock 2006), and arbuscular mycorrhizae (Camprubí et al. 2008; Nogales et al. 2008). However, to date, none of these treatments have been found to be completely effective and none of these treatments have been commercialized. Therefore, the need for the development of efficient control methods is crucial.

Although the genetic diversity of Armillaria spp. and its distribution in forests (Coetzee et al. 2005; Bendel et al. 2006; Mwenje et al. 2006; Prospero et al. 2008) and vineyards (Aguín-Casal et al. 2004; Pertot et al. 2008) have been extensively studied, the plant mechanisms involved in the interaction between the pathogen and its host plants have not received sufficient attention. In pot trials, young grapevines (2 years old) start to show symptoms of $A$. mellea infection and hyphal root penetration only from the second year after pathogen inoculation (Prodorutti et al 2009). These observations suggest the existence in young roots of a tolerance mechanism which delays root rot progress. This temporary resistance process could be an interesting starting point for the development of new disease-control approaches. Several studies have reported 
plant defense reactions against Armillaria spp. infection, including the accumulation of reactive oxygen species (ROS) and $\mathrm{pH}$ changes (Vítecek et al. 2005), the modulation of defense genes (Robinson et al. 2000, Wang et al. 2007), and the production of secondary metabolites (Isidorov et al. 2008). Also, in grapevine, the accumulation of free polyamines was observed nine months after A. mellea root inoculation, suggesting their possible role in signaling processes associated with the plant defense reaction (Nogales et al. 2008).

We provide evidence that a plant reaction is rapidly $(24 \mathrm{~h})$ activated in grapevine roots following $A$. mellea challenge. In particular, genes related to defense response, regulation of gene expression, and signal transduction are induced in the first stages of A. mellea attack. Moreover, the induction of genes involved in ethylene (ET) and jasmonate (JA) biosynthesis and response suggests the activation of the ET/JA signaling pathways in response to inoculation with this saproparasitic basidiomycete. We also demonstrate that the recombinant grapevine protein homologue of the Quercus robur phasechange-related protein can inhibit $A$. mellea growth in vitro.

\section{RESULTS}

\section{Isolation of $A$. mellea-induced grapevine cDNA clones.}

To study the early reaction of young grapevine roots to inoculation with $A$. mellea ( $24 \mathrm{~h}$ after inoculation), a subtracted cDNA library was constructed using a suppression subtractive hybridization (SSH) approach. The subtraction was done in forward, in order to enrich the library for cDNA sequences present in the A. mellea-inoculated Kober 5BB roots (tester) and absent from or less abundant in the untreated control roots (driver). In total, 2,226 clones were collected and subjected to further analysis. To search for true positives, all clones were polymerase chain reaction (PCR) amplified, spotted on nylon membranes, and screened by hybridization with four different cDNA probes: tester, driver, forward, and reverse subtracted. This analysis detected 56 clones that were upregulated in the A. mellea-treated roots.

\section{Sequence analysis and annotation.}

The sequencing of the 56 selected clones yielded 47 goodquality sequences, which were cleaned of primer and vector contaminations, and nine low-quality sequences, which were discarded. Insert lengths varied from 59 to $363 \mathrm{bp}$, with an average length of $185 \mathrm{bp}$. The 47 sequences were clustered into contigs in order to group the sequences with significant overlapping regions together, indicating that these sequences probably originated from the same cDNA. This procedure defined six clusters, derived from $25 \mathrm{SSH}$ sequences, plus 22 singletons. The clusters comprised two to seven SSH sequences and ranged from 154 to $335 \mathrm{bp}$ in length, with an average length of $228 \mathrm{bp}$. The size of the singletons ranged from 59 to $447 \mathrm{bp}$; the average size was $194 \mathrm{bp}$.

When aligned with the TIGR Grape Gene Index database, the 28 unique sequences were found to correspond with 24 tentative consensus (TC) sequences (Table 1). For the 47 sequenced cDNAs, the overall library redundancy was 1.9. Functional annotation of the TC sequences according to the Gene Ontology (GO) categories revealed that they were involved in different biological processes, such as defense response $(\mathrm{TC}=$ $4)$, response to stress $(\mathrm{TC}=1)$, hormone metabolism $(\mathrm{TC}=1)$, signal transduction $(\mathrm{TC}=3)$, regulation of gene expression

Table 1. Summary of the 28 suppression subtractive hybridization (SSH)-identified sequences isolated following Armillaria mellea treatment of Kober 5BB roots

\begin{tabular}{|c|c|c|c|c|c|c|}
\hline$\overline{\text { SSH } \text { code }^{a}}$ & Accession no. ${ }^{b}$ & $\mathbf{T C}^{\mathrm{c}}$ & Pinot Noir gene $^{d}$ & Definition $^{\mathrm{e}}$ & Homologous protein & $E$ value \\
\hline A08_2 & GR911643 & TC98523 & fgenesh.VV78X248522.8_1 & Protease inhibitor 1 (PIN1) & AAN85825 & $3.0 \mathrm{E}-34$ \\
\hline A03_7 & GR911640 & TC97254 & glimmer.VV78X012064.13_5 & Protease inhibitor 2 (PIN2) & AAN85825 & $2.0 \mathrm{E}-19$ \\
\hline A04_3 & GR911641 & TC91773 & glimmer.VV78X176033.9_1 & Thaumatin-like (TL) & AAD55090.1 & $1,0 \mathrm{E}-148$ \\
\hline A10_3 & GR911644 & TC97635 & No hit & Calmodulin $(\mathrm{CaM})$ & AAQ63461.1 & 9.E-79 \\
\hline A12_6 & GR911645 & TC93391 & glimmer.VV78X154025.18_1 & Phase-change related protein $(\mathrm{PCr})$ & CAB72442.1 & $5.0 \mathrm{E}-18$ \\
\hline E08 & GR911665 & TC93391 & No hit & $\mathrm{PCr}$ & CAB72442.1 & $5.0 \mathrm{E}-18$ \\
\hline B03 4 & GR911647 & TC82945 & glimmer.VV78X069566.6_1 & Tumor-related protein $(\mathrm{Tr})$ & AAC49969.1 & $9.0 \mathrm{E}-80$ \\
\hline B 08 & GR911650 & TC72587 & glimmer.VV78X271907.6_1 & Globulin (GLB) & AAM65577.1 & $5.0 \mathrm{E}-58$ \\
\hline B12 & GR911653 & TC72587 & glimmer.VV78X271907.6_1 & GLB & AAM65577.1 & $5.0 \mathrm{E}-58$ \\
\hline D05 & GR911658 & TC72587 & glimmer.VV78X271907.6_1 & GLB & AAM65577.1 & $5.0 \mathrm{E}-58$ \\
\hline E03 & GR911662 & TC72587 & No hit & GLB & AAM65577.1 & $5.0 \mathrm{E}-58$ \\
\hline $\mathrm{C} 05$ & GR911654 & TC94117 & glimmer.VV78X238526.9_6 & Proline-rich protein (Pro-R) & CAB85624.1 & $6,0 \mathrm{E}-22$ \\
\hline $\mathrm{C} 11$ & GR911657 & TC89821 & glimmer.VV78X179831.13_1 & Glutathione $S$-transferase (GST) & ABW34390.1 & $1.0 \mathrm{E}-96$ \\
\hline D08 & GR911659 & TC75061 & twinscan.VV78X191270.11_5 & Aminocyclopropane carboxylate oxidase (ACO) & Q08507 1 & $3.0 \mathrm{E}-160$ \\
\hline E04 & GR911663 & TC92611 & fgenesh.VV78X217483.10_1 & Transcription factor (TF) & CAA66481.1 & $3.0 \mathrm{E}-133$ \\
\hline A01 & GR911638 & TC100086 & fgenesh.VV78X086274.10_4 & Receptor-like protein kinase-related & NP_566697 & $3.0 \mathrm{E}-64$ \\
\hline A02 & GR911639 & TC84493 & fgenesh.VV78X114032.9_1 & Laccase & ACC78283.1 & $4.0 \mathrm{E}-125$ \\
\hline A05 & GR911642 & TC86622 & No hit & Unnamed protein product & CAO43937.1 & $7.0 \mathrm{E}-18$ \\
\hline B02 & GR911646 & TC 80320 & No hit & RNA polymerase & ACF06506.1 & $1.0 \mathrm{E}-57$ \\
\hline B04 & GR911648 & TC100606 & No hit & Extensin (class I) & AAA34163 & $2.0 \mathrm{E}-28$ \\
\hline B05 & GR911649 & TC87751 & fgenesh.VV78X012423.11_2 & Ca-dependent protein kinase & ABY28389 & $2.0 \mathrm{E}-75$ \\
\hline B09 & GR911651 & TC87587 & sim4.VV78X262027.9_2 & Ubiquitin-protein ligase & NP_565147.1 & $4.0 \mathrm{E}-86$ \\
\hline B10 & GR911652 & TC71862 & fgenesh.VV78X135834.21_3 & Pyrroline-5-carboxylate synthetase & CAB40834 & 0.0 \\
\hline $\mathrm{C} 09$ & GR911655 & TC 88813 & glimmer.VV78X278114.3_1 & Translation initiation factor & ACF06598.1 & $5.0 \mathrm{E}-78$ \\
\hline $\mathrm{C} 10$ & GR911656 & TC77750 & No hit & $\alpha$-Expansin & AAR09170.1 & $1.0 \mathrm{E}-125$ \\
\hline D04 & GR911661 & TC97529 & No hit & Translation initiation factor eIF1 & ACF06581.1 & $9.0 \mathrm{E}-55$ \\
\hline D09 & GR911660 & TC 82133 & glimmer.VV78X236086.8_2 & Short-chain dehydrogenase/reductase & NP_192713.1 & $5.0 \mathrm{E}-142$ \\
\hline E05 & GR911664 & TC72567 & sim4.VV78X096618.37_9 & Aspartate aminotransferase & NP_196713.1 & 0.0 \\
\hline
\end{tabular}

${ }^{a}$ Codes of singletons and clusters of the SSH-identified sequences. The SSH code of each cluster is defined by the longest sequence, and the numbers following the underscore correspond to the number of sequences in the cluster.

${ }^{\mathrm{b}}$ National Center for Biotechnology Information (NCBI) Gene Bank accession numbers of the SSH sequences.

${ }^{\mathrm{c}}$ The corresponding grapevine tentative consensus (TC) sequences were identified by a nucleotide BLAST search against the TIGR database (version 6.0).

${ }^{\mathrm{d}}$ The corresponding Pinot Noir genes were identified by a nucleotide BLAST search against the IASMA Pinot Noir predicted genes (release 3) (Velasco et al. 2007).

${ }^{\mathrm{e}}$ Definitions of grapevine genes are based on the homologous proteins identified via BLAST-X of TC sequences against the NCBI nonredundant database. The abbreviations of genes further characterized in this work are shown in parentheses. 
$(\mathrm{TC}=4)$, protein modification $(\mathrm{TC}=1)$, and cell wall organization $(\mathrm{TC}=3)$. Specifically, two different protease inhibitors (PIN1 and PIN2), which are similar to the grapevine PIN (Aziz et al. 2007; Belhadj et al. 2008); a thaumatin (TL); and a tumor-related $(\mathrm{Tr})$ protein that is homologous to a pathogeninduced trypsin inhibitor were identified. Moreover, the upregulation observed in the treated sample for genes that encode for enzymes involved in ethylene biosynthesis (aminocyclopropane-1-carboxylate oxidase) (ACO) and ROS detoxification (glutathione S-transferase) (GST) suggests that the defense reaction could be mediated by these signaling molecules. We also found genes coding for proteins involved in signal transduction pathways (one calmodulin and two protein kinases), in the regulation of gene expression (one transcription factor and one RNA polymerase), and in translation and protein modification (two translation initiation factors and one ubiquitin ligase). Genes coding for proteins associated with cell wall organization (one extensin, one expansin, and one laccase) also appeared to be induced.

Other induced genes whose functions were not directly linked to pathogen defense responses included a proline-rich (Pro-R) protein, a phase change-related $(\mathrm{PCr})$ protein, a globulin-like (GLB) protein, pyrroline-5-carboxylate synthetase, the shortchain dehydrogenase reductase, and an aspartate aminotransferase. We could not associate TC86622 with any GO biological process.

\section{Expression analysis of $\boldsymbol{A}$. mellea-induced genes.}

In order to validate the SSH results, we measured the relative expression of 11 genes (Table 2) by quantitative real-time reverse-transcriptase PCR (RT-qPCR) in the RNA samples used to construct the SSH library and in roots treated with $A$. mellea under greenhouse (Kober $5 \mathrm{BB}$ and Pinot Noir) or in vitro conditions (Kober 5BB). These genes were selected because they were putatively related to plant defense response (PIN1, $P I N 2, T r, T L, G S T, A C O, T F$, and $C a M$ ) or because they had never before been associated with this process (GLB, Pro-R, and $P C r$ ). The correct design of the primers was demonstrated by the expected size of the amplicon in RT-PCR experiments with grapevine cDNA. In addition, primer specificity was confirmed by the absence of amplification when using A. melleaderived cDNA as template (data not shown).

Table 2. Primer sequences of the selected suppression subtractive hybridization ( $\mathrm{SSH}$ )-identified genes and of some known pathogenesis-related (PR) markers and relative gene expression (fold change [FC]) of the SSH transcripts

\begin{tabular}{|c|c|c|c|c|c|}
\hline SSH code & Definition & Abbreviation & & RT-qPCR primer & FC $^{\mathbf{a}}$ \\
\hline A08_2 & Protease inhibitor 1 & PIN1 & $\begin{array}{l}\text { A08-2_for } \\
\text { A08-2_rev }\end{array}$ & $\begin{array}{l}\text { TCGTTACCCAAGATTTTTACTGCAC } \\
\text { ACCAACCCAATGAGCCTATCC }\end{array}$ & $4.8 \pm 0.3$ \\
\hline A03_7 & Protease inhibitor 2 & PIN2 & $\begin{array}{l}\text { A03-7_for } \\
\text { A03-7_rev }\end{array}$ & $\begin{array}{l}\text { GCTAGGACTGTAAAAGGCTGGTG } \\
\text { CGCAACTCCTGATAGATTGGTG }\end{array}$ & $4.1 \pm 0.2$ \\
\hline A04_3 & Thaumatin-like & $T L$ & $\begin{array}{l}\text { A04-3_for } \\
\text { A04-3_rev }\end{array}$ & $\begin{array}{l}\text { CTGGAGATGTATGGAACTGATAGTG } \\
\text { TCGGATTTTGAAGACCCTTTAC }\end{array}$ & $2.7 \pm 0.1$ \\
\hline A10_3 & Calmodulin & $\mathrm{CaM}$ & $\begin{array}{l}\text { A10-3_for } \\
\text { A10-3_rev }\end{array}$ & $\begin{array}{l}\text { TATTCCAGTAGTTTGGGTTGGTAGTG } \\
\text { AAGAAGCACCAAACAAGAAAGGAG }\end{array}$ & $2.2 \pm 0.2$ \\
\hline A12_6 & Phase change-related protein & $\mathrm{PCr}$ & $\begin{array}{l}\text { A12-6_for } \\
\text { A12-6_rev }\end{array}$ & $\begin{array}{l}\text { CTTCTCTTTGCTGTTGTTCTCATCC } \\
\text { ACTTCGCATCCTCCACGCT }\end{array}$ & $5.9 \pm 0.3$ \\
\hline B03_4 & Tumor-related protein & $\operatorname{Tr}$ & $\begin{array}{l}\text { B03-4_for } \\
\text { B03-4_rev }\end{array}$ & $\begin{array}{l}\text { TGTGTGATTTCTGCAAGCCTGT } \\
\text { GCCAAACGCCTGTATCCATT }\end{array}$ & $3.8 \pm 0.2$ \\
\hline $\mathrm{C} 05$ & Proline-rich protein & Pro- $R$ & $\begin{array}{l}\text { C05_For } \\
\text { C05_Rev }\end{array}$ & $\begin{array}{l}\text { CTCAGGACACAAGCCACCA } \\
\text { GCTTTATCTTTGGAGGTATCTT }\end{array}$ & $2.5 \pm 0.1$ \\
\hline $\mathrm{C} 11$ & Glutathione S-transferase & $G S T$ & $\begin{array}{l}\text { C11_For } \\
\text { C11_Rev }\end{array}$ & $\begin{array}{l}\text { CACAAAACTACCACCCACCAA } \\
\text { TCCTCACTCTCTTCAATCACTT }\end{array}$ & $2.2 \pm 0.1$ \\
\hline D05 & Globulin & $G L B$ & $\begin{array}{l}\text { D05_for } \\
\text { D05_rev }\end{array}$ & $\begin{array}{l}\text { GCCTCTCTCAATGTGGCTCC } \\
\text { TGCTCTTTTTGATCTTTGCCC }\end{array}$ & $6.3 \pm 0.3$ \\
\hline D08 & Aminocyclopropane carboxylate oxidase & $A C O$ & $\begin{array}{l}\text { D08_For } \\
\text { D08_Rev }\end{array}$ & $\begin{array}{l}\text { CACTCCATTGTGGTCAACCT } \\
\text { CATCCTGTTGCCGTCTGTTT }\end{array}$ & $2.3 \pm 0.1$ \\
\hline E04 & Transcription factor & $T F$ & $\begin{array}{l}\text { E04_for } \\
\text { E04_rev }\end{array}$ & $\begin{array}{l}\text { TGAGATTTTGTCTTACCCCCCA } \\
\text { TTCTAGTCAATTTCCCGCTCAAG }\end{array}$ & $2.3 \pm 0.1$ \\
\hline- & Thaumatin $1^{\mathrm{b}}$ & $T L 1$ & $\begin{array}{l}\text { TL1_For } \\
\text { TL1_Rev }\end{array}$ & $\begin{array}{l}\text { TGGGCGTGGCAAATGCGAAA } \\
\text { CGAGGTTATTGGGCTGGTTTA }\end{array}$ & \\
\hline - & Pathogenesis-related protein $1^{\mathrm{c}}$ & $P R-1$ & $\begin{array}{l}\text { PR-1_For } \\
\text { PR-1_Rev }\end{array}$ & $\begin{array}{l}\text { ACTTGTGGGTGGGGGAGAA } \\
\text { TGTTGCATTGAACCCTAGCG }\end{array}$ & \\
\hline- & Pathogenesis-related protein $4^{\mathrm{c}}$ & $P R-4$ & $\begin{array}{l}\text { PR-4_For } \\
\text { PR-4_Rev }\end{array}$ & $\begin{array}{l}\text { CAGGCAACGGTGAGAATAGT } \\
\text { ACCACAGTCCACAAACTCGTA }\end{array}$ & \\
\hline- & Lipoxygenase $9^{c}$ & $L O X-9$ & $\begin{array}{l}\text { LOX9_For } \\
\text { LOX9_Rev }\end{array}$ & $\begin{array}{l}\text { CCCTTCTTGGCATCTCCCTTA } \\
\text { TGTTGTGTCCAGGGTCCATTC }\end{array}$ & \\
\hline- & Vegetative storage protein ${ }^{\mathrm{d}}$ & $V S P$ & $\begin{array}{l}\text { VSP_For } \\
\text { VSP_Rev }\end{array}$ & $\begin{array}{l}\text { CGGTACAGGTCGGACTCG } \\
\text { GCGTAGTAGGGCAGATTGGA }\end{array}$ & \\
\hline- & Pathogenesis-related protein $2^{\mathrm{e}}$ & $P R-2$ & $\begin{array}{l}\text { PR-2_For } \\
\text { PR-2_Rev }\end{array}$ & $\begin{array}{l}\text { GTTATTTCAGAGAGTGGTTGGC } \\
\text { AACATGGCAAACACGTAAGTCT }\end{array}$ & \\
\hline- & $\operatorname{Actin}^{\mathrm{f}}$ & Act & $\begin{array}{l}\text { ACT_For } \\
\text { ACT_Rev }\end{array}$ & $\begin{array}{l}\text { TCCTTGCCTTGCGTCATCTAT } \\
\text { CACCAATCACTCTCCTGCTACAA }\end{array}$ & \\
\hline
\end{tabular}

${ }^{a}$ Relative expression level (FC) of Kober 5BB genes in roots $24 \mathrm{~h}$ after inoculation with Armillaria mellea (tester) compared with the untreated root (driver) samples used for SSH library construction. Values are means and standard errors of three technical replicates.

${ }^{\mathrm{b}}$ Sequence of the antifungal protein thaumatin 1 (AF003007) as reported by Jayasankar and associates (2003).

${ }^{c}$ PR-1 (AJ536326, TC56938) was used as a marker gene for the salicylic acid (SA) pathway. PR-4 (CF074510, TC58333) and LOX-9 (AY159556, TC63584) served as marker genes for jasmonate (JA) signaling. Sequences were taken from Hamiduzzaman and associates (2005).

${ }^{\mathrm{d}}$ Grapevine VSP gene (TC64921), which is homologous to the JA-inducible Arabidopsis thaliana VSP (AT5G24780, Z18377.1) (van Wees et al. 1999), was identified through a BLAST-X search of the TIGR database (version 6.0).

${ }^{\text {e }}$ Grapevine $P R-2$ gene (TC64809), which is homologous to the SA-inducible A. thaliana PR-2 (AT3G57260, M90509.1) (van Wees et al. 1999), was identified through a BLAST-X search of the TIGR database version 6.0.

${ }^{\mathrm{f}}$ Grapevine Act gene (TC100707) was used as a constitutive gene for normalization of the quantitative real-time reverse-transcriptase polymerase chain reaction (RT-qPCR) data (Gatto et al. 2008). 
As expected, significant induction (more than twofold) of all of the selected grapevine genes was observed comparing the tester with the driver RNA samples used to construct the SSH library (Table 2).

Gene expression analyses performed in greenhouse-grown plants detected the significant upregulation of the PIN1, PIN2, $\operatorname{Tr} T L, G L B, P C r$, Pro-R, GST, and ACO genes and the control gene, thaumatin $1(T L 1)$, in young roots of Kober $5 \mathrm{BB}$ and Pinot Noir $24 \mathrm{~h}$ after inoculation with A. mellea (Fig. 1). However, in Pinot Noir, the levels of induction of PIN1, PIN2, Tr, $G L B$, and $G S T$ and ACO expression were approximately half of those observed in Kober 5BB. The expression of the SSHidentified genes was not modulated in untreated grapevine roots (incubated in $10 \mathrm{mM} \mathrm{MgCl} 2$ solution for $24 \mathrm{~h}$ ), confirm-
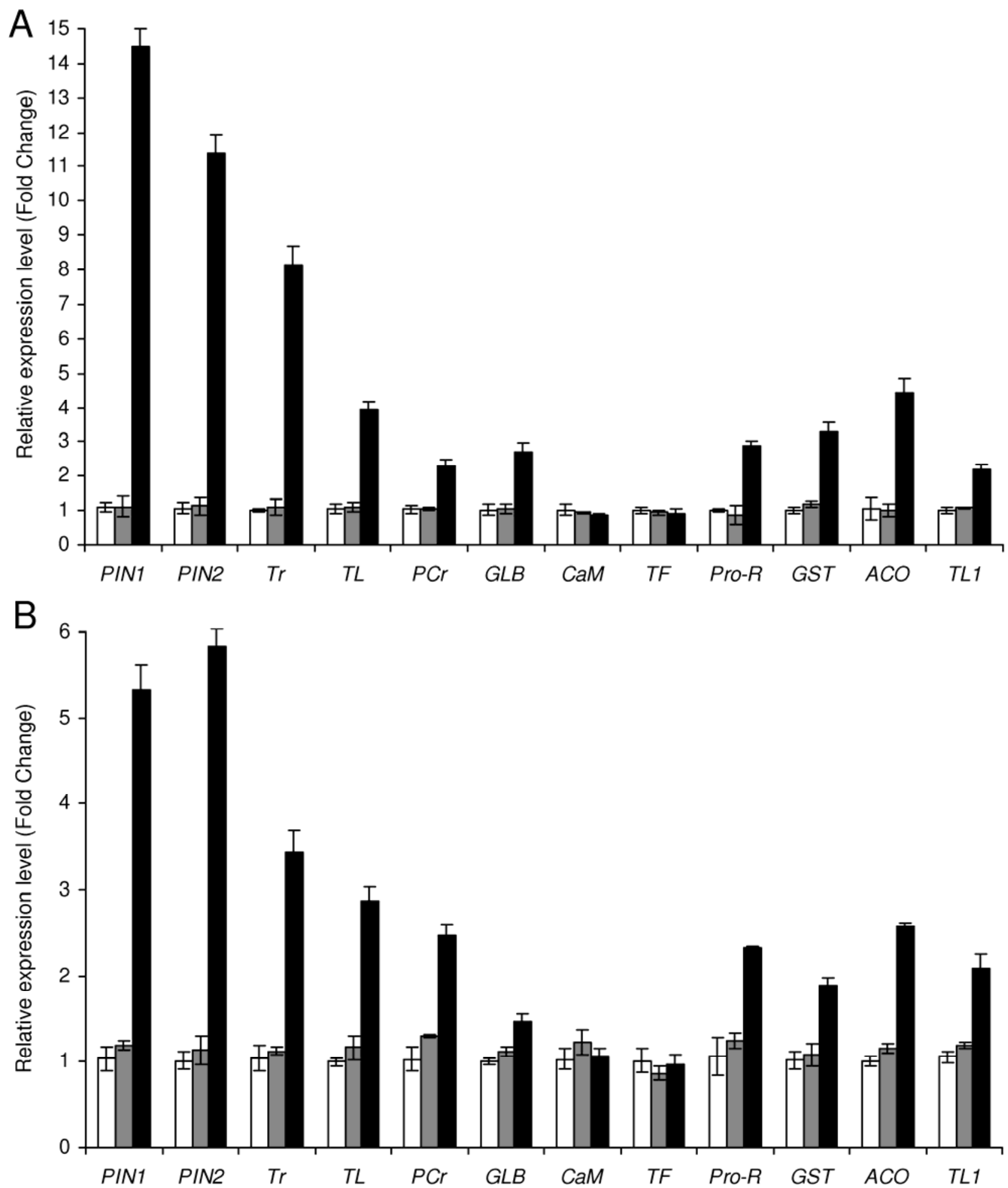

Fig. 1. Quantitative real-time reverse-transcriptase polymerase chain reaction analysis of the expression of suppression subtractive hybridization-identified grapevine genes in roots of $\mathbf{A}$, Kober 5BB rootstock and $\mathbf{B}$, ungrafted Pinot Noir plants grown under controlled greenhouse conditions. Relative expression levels (fold change) of the specified genes $24 \mathrm{~h}$ after Armillaria mellea treatment (black) and $24 \mathrm{~h}$ after incubation in the $\mathrm{MgCl}_{2}$ solution (gray), compared with untreated roots (white). Mean levels of relative expression and standard errors from three biological replicates of each treatment of one representative experiment are presented. 
ing the absence of nonspecific gene modulation during the incubation of roots without the pathogen. No A. melleadependent induction of the $C a M$ and $T F$ genes was observed in the Kober 5BB or Pinot Noir roots.

To prolong the infection time and to confirm the results at $24 \mathrm{~h}$ under sterile conditions, in vitro-grown plants were inoculated with A. mellea. These same plants were also examined under a microscope, revealing that $A$. mellea mycelia had penetrated the root cortex 10 days after pathogen inoculation (Fig. 2).

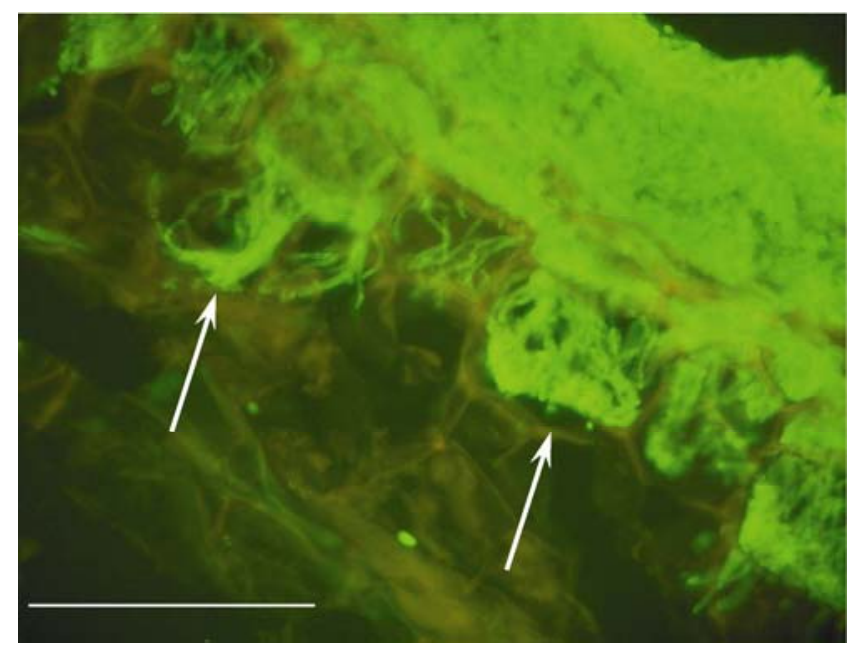

Fig. 2. Armillaria mellea mycelium (arrows) in root sections of in vitrogrown Kober 5BB plants after FITC-WGA staining (Meyberg 1988), as viewed under a fluorescent microscope (10 days after inoculation with $A$. mellea). No green fluorescence was observed in root sections from untreated control plants that had been incubated in a $10 \mathrm{mM} \mathrm{MgCl}_{2}$ solution for 10 days. The scale bar represents $100 \mu \mathrm{m}$.
The RT-qPCR analysis revealed that, at $24 \mathrm{~h}$ after inoculation, genes were more strongly induced in the in vitro experiments than in the greenhouse treatments (Fig. 3). In particular, PIN2 and $T r$ were upregulated a hundred times more in the inoculated roots than in untreated control roots, and PIN1, TL1, TL, $G L B, G S T$, and $A C O$ genes were strongly induced (from 2- to 20 -fold) as well. These genes were also highly expressed $96 \mathrm{~h}$ after $A$. mellea treatment; whereas the expression of Pro- $R$ was induced only at $96 \mathrm{~h}$, not at $24 \mathrm{~h}$. The absence of gene modulation in the control sample after 24 and $96 \mathrm{~h}$ of incubation in 10 $\mathrm{mM} \mathrm{MgCl} 2$ solution indicates that the induction of these genes is a specific $A$. mellea-dependent reaction. The in vitro experiments confirmed the absence of modulation of $C a M$ and $T F$, as had been indicated by the results of the greenhouse experiments.

In addition, the expression of four genes known as salicylic acid (SA)- or ET/JA-signaling markers was analyzed (Fig. 4). RT-qPCR data showed no modulation of the pathogenesisrelated (PR) protein 1 gene $(P R-1)$ or $P R-2$, which are both markers of the SA pathway. However, A. mellea-dependent induction of typical ET/JA signaling genes such as a lipoxigenase $9(L O X-9)$ and a vegetative storage protein (VSP) was detected under all tested conditions, whereas no expression of $P R-4$ was detected in the root samples.

\section{Isolation of full-length cDNAs and their expression as recombinant proteins.}

PIN 1, PIN2, TL, Tr, PCr, GLB, and Pro-R were further characterized to investigate their roles in the root response to A. mellea. We first obtained the full-length coding sequences (CDS) and subsequently cloned them into an expression vector to produce the corresponding recombinant proteins (Table 3).

The analysis of the short SSH sequences corresponding to the genes listed above revealed that the sequences encompassed the stop codon of the gene but were truncated at the $5^{\prime}$

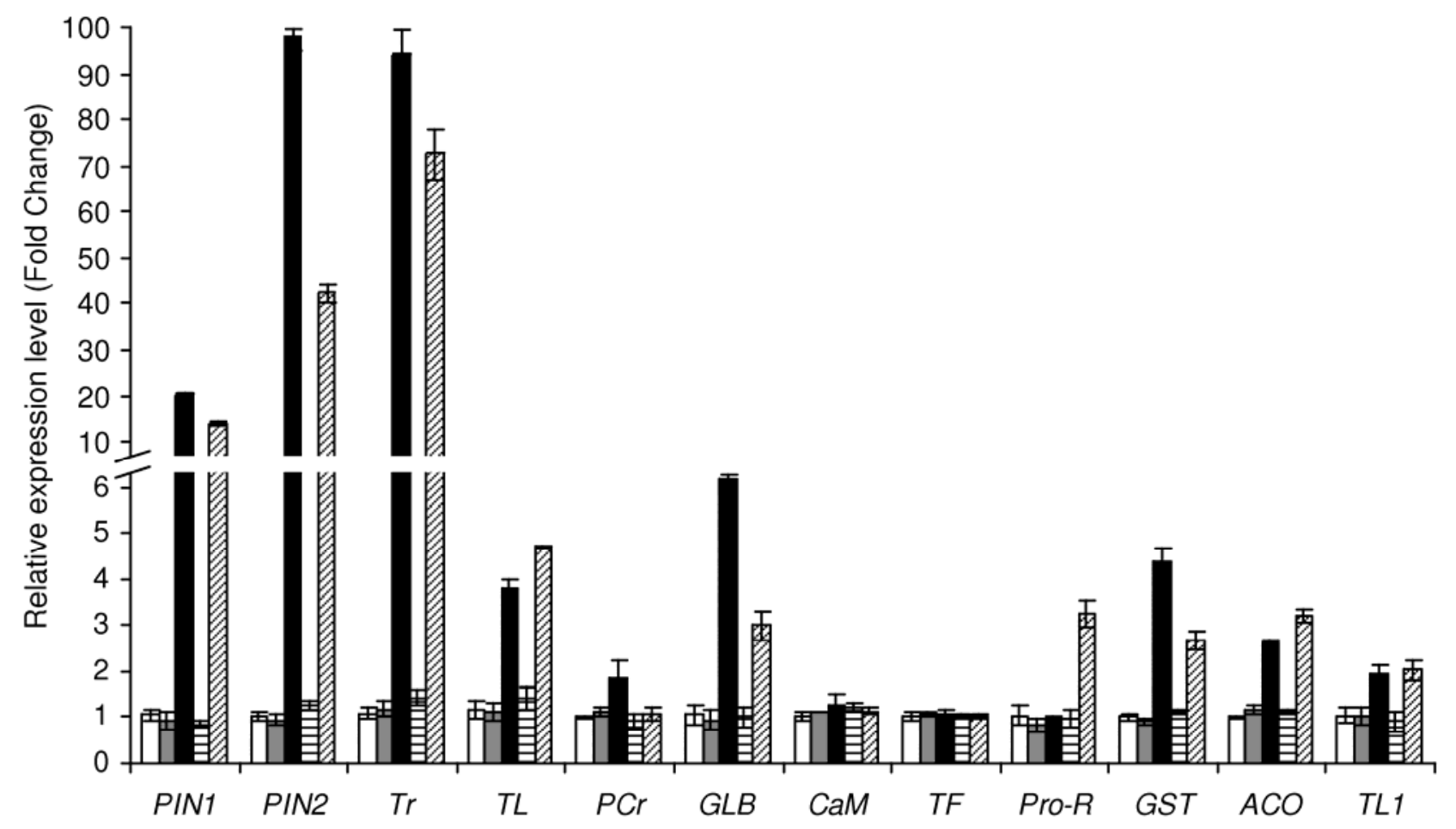

Fig. 3. Quantitative real-time reverse-transcriptase polymerase chain reaction analysis of the expression of suppression subtractive hybridization-identified grapevine genes in roots of Kober 5BB plants grown in vitro. Relative expression levels (fold change) of the specified genes at $24 \mathrm{~h}$ (black) and $96 \mathrm{~h}$ (diagonal lines) after Armillaria mellea inoculation, and after $24 \mathrm{~h}$ (gray) and $96 \mathrm{~h}$ (horizontal lines) of incubation in the $\mathrm{MgCl}_{2}$ solution, compared with untreated roots (white). Mean levels of relative expression and standard errors from three biological replicates of each treatment of one representative experiment are presented. 
end and, therefore, were missing the ATG start codon. To clone the full-length CDS, we used a 5' rapid amplification of cDNA ends (RACE) RT-PCR protocol involving gene-specific primers (Supplementary Table 1). In parallel, the CDS of the Kober 5BB cystatin-1 gene (CYS1), which is homologous to the antifungal strawberry phytocystatin Cyfl (Martinez et al. 2005), was also obtained. The comparison of the cloned sequences with the SSH sequences and the homologous sequences from other species confirmed the successful isolation of the corresponding full-length gene. The presence of a putative signal peptide was predicted in the protein sequences of Tr, TL, PCr, GLB, Pro-R, and CYS1 (Table 3).

The sequences coding for the mature proteins were cloned for heterologous expression in Escherichia coli as fusion constructs with histidine tags. PIN1, PIN2, GLB, PCr, Pro-R, and CYS1 proteins were expressed at high levels in the soluble fraction and were purified to homogeneity by affinity chromatography (Table 3). Though different expression conditions were tested, we were not able to express the recombinant $\mathrm{Tr}$ protein and we could produce TL only as insoluble inclusion bodies.

\section{Antimicrobial activity test of the recombinant proteins.}

Tests of the antifungal activity of the six purified recombinant grapevine proteins demonstrated that $\mathrm{PCr}$ can significantly inhibit A. mellea growth in vitro (30 $\pm 4 \%$ growth inhibition) when present at concentration of $60 \mu \mathrm{mol}$. The dose-response study showed that $\mathrm{PCr}$ activity was concentration dependent (Fig. 5A) from $2.5 \mu \mathrm{M}(17 \mu \mathrm{g} / \mathrm{ml})$ through $400 \mu \mathrm{M}(46 \pm 4 \%$ inhibition), with a subsequent saturation effect at higher dose. In contrast, no significant effects on A. mellea growth were observed for PIN1 ( $4 \pm 3 \%$ of inhibition), PIN2 (4 $\pm 3 \%$ ), GLB $(4 \pm 2 \%)$, Pro-R $(3 \pm 3 \%)$, or CYS1 $(3 \pm 3 \%)$ at $120 \mu \mathrm{M}$ (Fig. 5B) or lower concentrations $(2.5,12.5$, and $60 \mu \mathrm{M})$. The absence of any effects against $A$. mellea was confirmed for PIN1 (5 $\pm 3 \%$ of inhibition), GLB ( $8 \pm 5 \%$ ), and CYS1 ( $3 \pm$ $3 \%$ ), also at $400 \mu \mathrm{M}$. The absence of any synergistic effects between the purified proteins was demonstrated by applications of mixtures of the recombinant proteins (data not shown).

The in vitro antimicrobial activity of the proteins against another necrotrophic plant-pathogenic fungus and two gramnegative bacteria was evaluated. In particular, we examined the effects of these proteins against Botrytis cinerea, E. coli, and
Pseudomonas fluorescens. PCr, but not PINs, GLB, or Pro-R, was able to inhibit $B$. cinerea growth when applied at a high dosage $(200 \mu \mathrm{g})$ (data not shown). A small zone of inhibition was also observed when the same amount of CYS1 was applied, suggesting that this grapevine protein might be slightly active

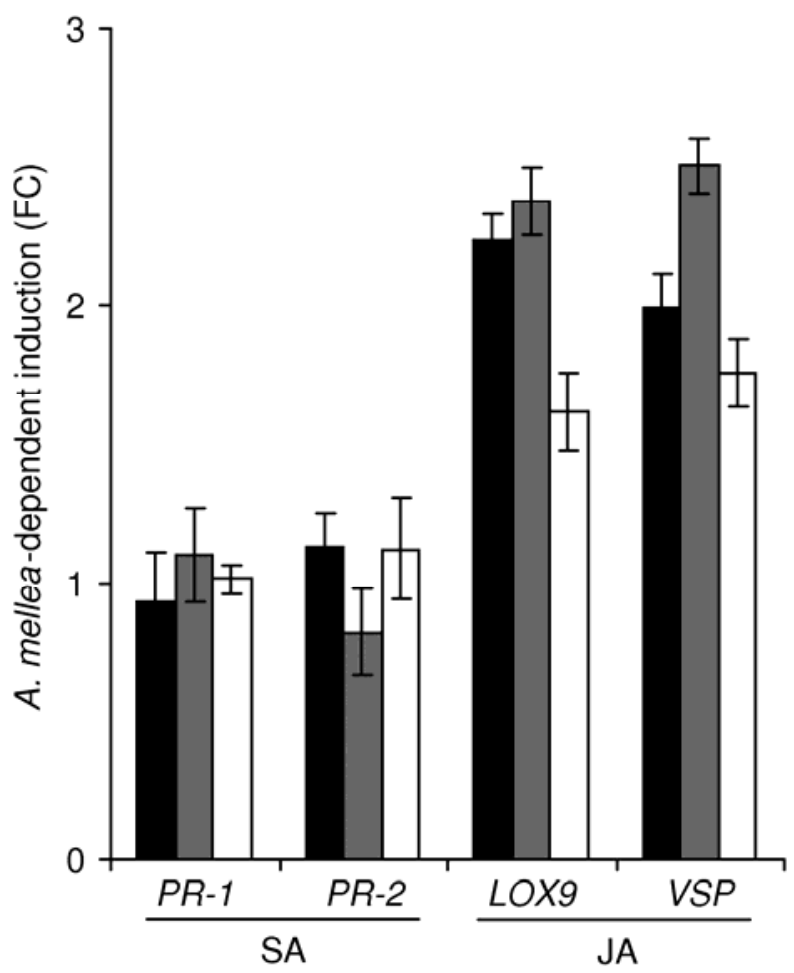

Fig. 4. Quantitative real-time reverse-transcriptase polymerase chain reaction analysis of the expression of gene markers of the salicylate (SA) and ethylene and jasmonate (ET/JA) signaling pathways in the roots of Kober $5 \mathrm{BB}$ plants grown under greenhouse (black) or in vitro (gray) conditions, and ungrafted Pinot Noir plants grown under greenhouse conditions (white). Relative expression levels (fold change [FC]) $24 \mathrm{~h}$ after Armillaria mellea inoculation were calculated with respect to control roots that had been incubated in $10 \mathrm{mM} \mathrm{MgCl} 2$ solution for $24 \mathrm{~h}$. Mean levels of relative expression and standard errors from three biological replicates of each treatment of one representative experiment are presented.

Table 3. Properties of the recombinant Kober 5BB mature proteins purified for functional characterization

\begin{tabular}{|c|c|c|c|c|c|c|c|c|}
\hline \multirow[b]{2}{*}{ Abbreviation } & \multirow[b]{2}{*}{ Accession no. } & \multirow[b]{2}{*}{ Coding sequence (bp) } & \multirow[b]{2}{*}{ Signal peptide ${ }^{c}$} & \multirow[b]{2}{*}{$\operatorname{MW}(\mathbf{k D a})^{\mathbf{d}}$} & \multicolumn{2}{|c|}{ SDS-PAGE $^{a}$} & \multicolumn{2}{|c|}{ Protein } \\
\hline & & & & & Pellet & Soluble & Soluble $(\mathrm{mg})^{\mathrm{e}}$ & 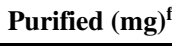 \\
\hline PIN1 & GQ427141 & 216 & - & 7.8 & + & + & 24.0 & 1.2 \\
\hline PIN2 & GQ427142 & 222 & - & 8.0 & + & + & 12.2 & 0.6 \\
\hline $\operatorname{Tr}$ & GQ427143 & 612 & $+(24)$ & 20.0 & - & - & 6.2 & 0 \\
\hline TL & GQ427144 & 720 & $+(20)$ & 23.9 & + & - & 6.4 & 0 \\
\hline $\mathrm{PCr}$ & GQ427145 & 279 & $+(26)$ & 6.8 & + & + & 15.0 & 0.9 \\
\hline GLB & GQ427146 & 1,076 & - & 38.5 & + & + & 22.0 & 1.8 \\
\hline Pro-R & GQ427147 & 402 & $+(22)$ & 12.0 & + & + & 19.7 & 0.3 \\
\hline CYS1 $^{\mathrm{g}}$ & GQ427148 & 705 & $+(22)$ & 24.3 & + & + & 23.0 & 1.8 \\
\hline Empty vector $^{\text {h }}$ & - & - & - & - & - & - & 27.9 & 0 \\
\hline
\end{tabular}

a Sodium dodecyl sulfate polyacrylamide gel electrophoresis (SDS-PAGE) results for the presence (+) of the recombinant proteins in the soluble or insoluble fractions.

b National Center for Biotechnology Information Gene Bank accession number of the sequences obtained by 5 ' rapid amplification of cDNA ends reversetranscriptase polymerase chain reaction and containing the full-length coding sequences.

${ }^{c}$ Presence of a putative N-terminal signal peptide is based on SignalP software and the number of amino acid residues is indicated in parentheses.

d Translations to protein sequences and estimations of the molecular masses of the mature proteins were done using the ExPASy Proteomics Server, and these estimates include the first Met and exclude the fused His-tag.

e Milligrams of total soluble protein obtained after centrifugation of lysate from $100 \mathrm{ml}$ of bacterial culture (2 $\mathrm{g}$ of cells).

${ }^{\mathrm{f}}$ Milligrams of purified protein from $100 \mathrm{ml}$ of bacterial culture ( $2 \mathrm{~g}$ of cells).

g Sequence of Kober 5BB cystatin 1 (CYS1) was obtained by amplification with primers designed based on TC89650 (TIGR Grape database v. 6.0), the homologue of the strawberry Cyfl gene, which codes for a phytocystatin with antifungal properties (Martinez et al. 2005).

${ }^{\mathrm{h}}$ Escherichia coli cells transformed with the empty pET22b were used as a control to test the unspecific binding to the affinity chromatography gel. 
against $B$. cinerea but is not active against $A$. mellea. $\mathrm{PCr}$ displayed antibacterial activity against $E$. coli TOP10 and $P$. fluorescens WCS417r (Fig. 6), with estimated half maximal inhibitory concentration $\left(\mathrm{IC}_{50}\right)$ values of $3 \mu \mathrm{g} / \mathrm{ml}(0.44 \mu \mathrm{M})$ and less
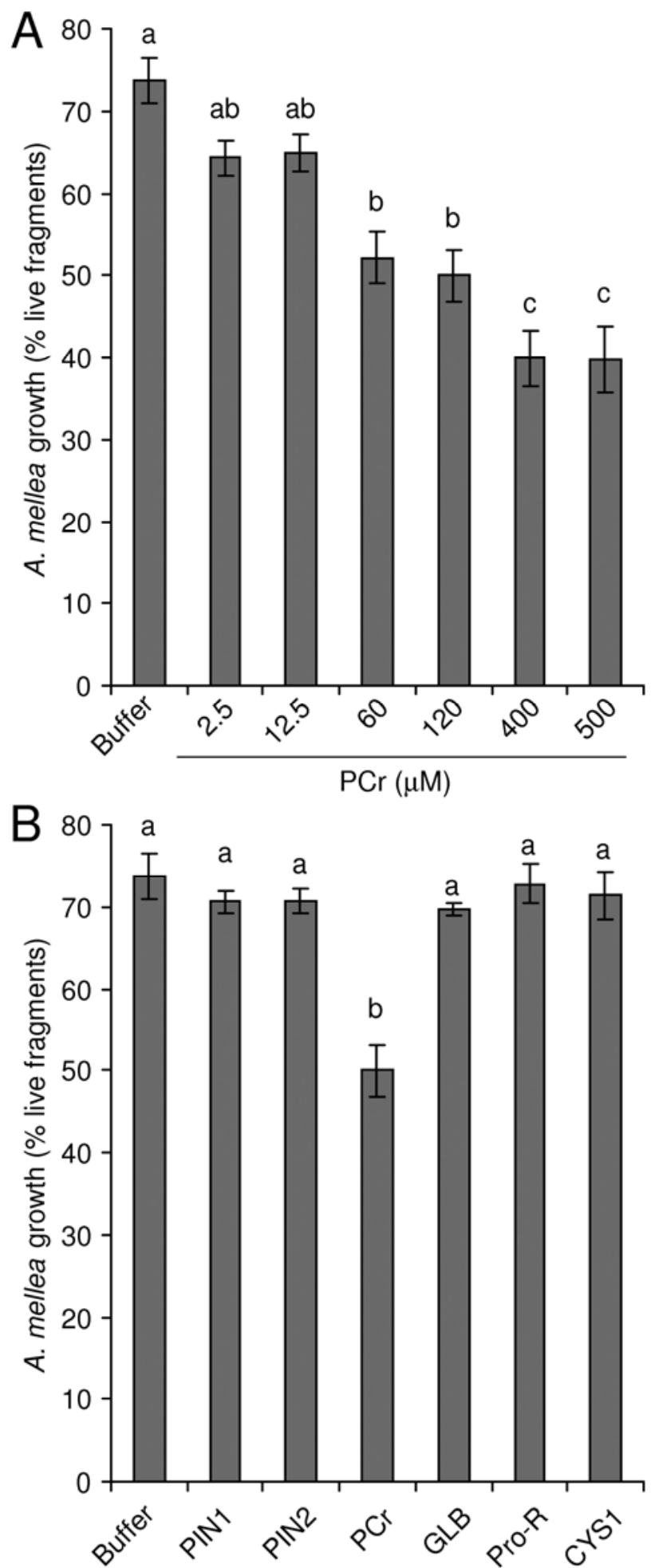

Fig. 5. Test of antifungal activity against Armillaria mellea of A, different concentrations of the purified phase change-related $(\mathrm{PCr})$ protein and $\mathbf{B}$, a $120 \mu \mathrm{M}$ solution of the purified grapevine recombinant proteins: PIN1, PIN2, PCr, GLB, Pro-R, and CYS. Mean percentage and standard error (six replicates) of live $A$. mellea fragments, calculated with respect to the total number of A. mellea fragments, are presented for each treatment. Results of one representative experiment are shown. Different letters indicate significant differences according to Tukey's test $(P<0.05)$. than $3 \mu \mathrm{g} / \mathrm{ml}$, respectively. In contrast, PIN1, PIN2, GLB, Pro$\mathrm{R}$, and CYS1 did not display any antibacterial activity in this experiment.

\section{DISCUSSION}

The aim of this work was to characterize the response of young roots to A. mellea and to identify grapevine genes that are modulated during the first stages of this interaction. We employed a cDNA SSH approach (Diatchenko et al. 1996) to specifically isolate gene sequences whose expression is induced during the grapevine reaction to A. mellea. Kober 5BB plants were chosen in this study because this hybrid is a commonly used rootstock. Based on a report that cultured tobacco cells respond quickly to A. mellea elicitors (Vítecek et al. 2005), root samples were collected $24 \mathrm{~h}$ after inoculation. As it was, the experimental set-up did not allow us to distinguish between the plant defense reaction to A. mellea elicitors and the more general stress response due to wounding or mechanical penetration. Our analysis of the SSH clones indicates that grapevine roots respond to A. mellea challenge with rapid upregulation of the expression of some genes. The annotation of this gene set suggests the activation of a whole defense process, because the set includes genes involved in signal transduction (calmodulin and protein kinases), hormone metabolism $(A C O)$, transcription and translation (transcription factor, RNA polymerase, and translation initiation factors), protein modification (ubiquitin ligase), cell wall organization (extensin, expansin, and laccase), defense response (PIN1, PIN2, $T L$, and $T r$ ), and response to stress (GST). Interestingly, among the induced transcripts, we also found sequences whose functions have not been previously linked to plant defense re-

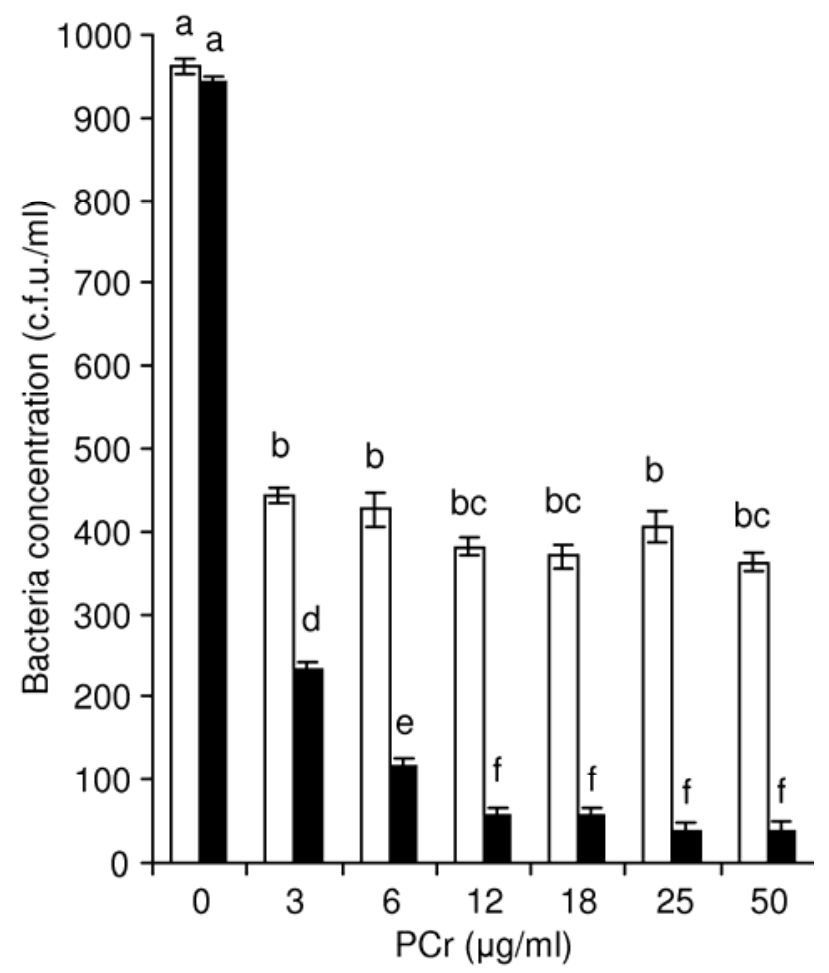

Fig. 6. Test of activity against Escherichia coli TOP10 (white) and Pseudomonas fluorescens WCS417r (black) incubated in the presence of different concentrations of the purified phase change-related ( $\mathrm{PCr}$ ) protein. For each treatment, the mean number of CFU and standard error from six replicates are presented. Results of one representative experiment are shown. Different letters indicate significant differences according to Tukey's test $(P<0.05)$. 
actions, such as PCr, GLB, and Pro-R; genes associated with cellular metabolism (coding for pyrroline-5-carboxylate synthetase and aspartate aminotransferase); as well as genes of unknown functions.

ET is known to contribute to plants' resistance to necrotrophic pathogens, whereas SA primarily mediates plant resistance to biotrophs (van Loon et al. 2006). ET usually exerts its resistance-stimulating activity in concert with JA, and ET/JA signals negatively affect the SA signaling pathway to finely tune plants' defense responses (Pieterse et al. 2009). During the grapevine reaction to $A$. mellea, we observed the modulation of transcripts that are involved in ET or JA biosynthesis as well as the modulation of genes known to be under ET/JA control in other systems. This group includes the gene encoding for the last enzyme of the ET biosynthetic pathway (ACO); two class V PR genes, $T L$ and $T L 1$, shown to be induced by ET (Jacobs et al. 1999); as well as the protease inhibitor genes $P I N$ and $T r$, which appeared to be modulated by JA (Tsukuda et al. 2006; Belhadj et al. 2008). The significant involvement of the ET/JA signals was also corroborated by the higher levels of $L O X-9$ and VSP expression observed in the treated roots. These genes are markers of the JA signaling pathway in grapevine (Hamiduzzaman et al. 2005) and Arabidopsis thaliana (van Wees et al. 1999), respectively. Also, no induction of $P R-1$ or $P R-2$, markers of the SA pathway (van Wees et al. 1999; Hamiduzzaman et al. 2005), was observed. Therefore, our results clearly indicate the activation of the ET/JA-mediated defense signaling pathways in grapevine roots following $A$. mellea challenge.

The accumulation of ROS is commonly observed during plant defense reactions, where they play multiple roles as toxic or signaling molecules (Apel and Hirt 2004) against necrotrophic pathogens, too (Shetty et al. 2008). The twofold upregulation of GST expression in A. mellea-treated roots, in both the greenhouse and in vitro experiments, suggests the possible accumulation of ROS during the grapevine reaction. Indeed, GST encode for ROS-detoxifying enzymes and their expression is induced by ROS (Lamb and Dixon 1997), and accumulation of ROS has also been observed in cultured tobacco cells 15 to 20 min after treatment with $A$. mellea extracts and lipids (Vítecek et al. 2005).

The downstream effect of the defense-related signals seems to be the upregulation of a set of defense genes belonging to well-known classes of PR genes, as mentioned above, as well as genes that have not yet been directly associated with any biological process. In all of the experiments, the highest level of A. mellea-dependent induction was observed for genes encoding protease inhibitors, such as PIN1, PIN2, and Tr. The serine-protease inhibitors encoded by $P I N$ genes are small proteins belonging to the PR- 6 class that display activity against fungal pathogens (Sels et al. 2008). Previous reports have shown that the grapevine $P I N$ is activated by methyl jasmonate (Belhadj et al. 2008) and some elicitors of plant defense responses (Aziz et al. 2007), suggesting that it is the final effector of a network of signals. The grapevine Tr protein contains the typical Kunitz-type trypsin inhibitor motif and is very similar to a tumor-related protein found in tobacco and to a miraculin-like protein (LeMir) found in tomato. The tobacco $\operatorname{Tr}$ gene is able to elicit a hypersensitive response (HR) (Karrer et al. 1998) and LeMir was shown to be rapidly induced upon nematode infection and secreted into the surrounding root environment (Brenner et al. 1998). The high sequence homology and the root induction following exposure to soilborne microorganisms suggest that the grapevine Tr and LeMir genes may be functional homologues. Among the A. mellea-induced genes that belong to the PR-5 class, we found a $T L$ gene that differs from the characterized TL1 and TL2 (Jacobs et al. 1999;
Jayasankar et al. 2003). Interestingly, the results of expressed sequence tag analysis indicate that the $\mathrm{SSH}$-identified $T L$ is expressed mainly in roots and in berries exposed to abiotic stress. In grapevine, the expression of $P R-5$ genes is upregulated in leaves infected with powdery mildew (Jacobs et al. 1999), and PR-5 proteins accumulate in berries and leaves that have been inoculated with B. cinerea or Phomopsis viticola (Monteiro et al. 2003). Activity tests have shown that these proteins display antifungal activity against biotrophic and necrotrophic grapevine pathogens (Jayasankar et al. 2003; Monteiro et al. 2003).

Although we observed A. mellea-dependent gene induction in both greenhouse- and in vitro-grown plants, the extent of modulation was generally much greater in the latter growth system. This could be due to a stronger reaction of the young root tissues or to more extensive contact with fungal inoculum in the in vitro experiments. The rapid penetration of the cortical plant tissues by the pathogen's hyphae, observed 10 days after in vitro A. mellea inoculation, supports both of these proposed hypotheses. However, the involvement of the same defense mechanisms in the in vitro- and greenhouse-grown Kober 5BB plants, as well as the Pinot Noir plants, seems very likely because, generally, the same genes were induced in all the experimental set-ups. Exceptions were the Pro- $R$ and $\mathrm{PCr}$ genes, the first one being induced only in the greenhouse experiments and the second one not showing the increase in modulation usually observed when comparing in vitro and greenhouse gene expression results. Higher levels of expression of the defense genes in the non-Vitis vinifera species have been reported in previous studies and linked to the resistant phenotype (Kortekamp 2006; Figueiredo et al. 2008). A stronger gene induction was found in the hybrid Kober 5BB compared with $V$. vinifera Pinot Noir roots and this result is in line with recent findings showing that Kober $5 \mathrm{BB}$ displays a moderate resistance to A. mellea artificial inoculations (Prodorutti et al. 2009). Furthermore, the strong induction of the $P R$ genes within the first $24 \mathrm{~h}$ following inoculation supports the hypothesized regulation of the encoded proteins at the transcriptional level in the early phases of the plants' response. Although a final conclusion will come only after protein quantification and characterization, several reports have suggested the possibility of large-scale transcriptional reprogramming of defense genes following pathogen recognition (Eulgem 2005).

An essential step in the investigation of the role of the SSHidentified genes in the grapevine response against $A$. mellea was the assay of their inhibitory effect on the growth of this fungus. PCr protein inhibited A. mellea growth already at 2.5 $\mu \mathrm{M}(17 \mu \mathrm{g} / \mathrm{ml})$ and a significant effect (25\% of inhibition) was measured at $60 \mu \mathrm{M}$, displaying a dose dependence. Though apparently high, a similar range of active concentrations was reported for other antifungal proteins (Lee et al. 2008). The PCr amino acid sequence looks similar (>60\%), among the others, to that of an antimicrobial peptide isolated from Capsella bursa-pastoris roots that has been named shepherin. Shepherins are cationic peptides rich in Gly and His residues, which probably exert their antimicrobial activity by interacting with the negative surfaces of cell membranes (Park et al. 2000). The Capsella shepherin gene codes for two peptides, shepherin I and II, whose maturation involves proteolytic cleavage (Park et al. 2000). The grapevine $\mathrm{PCr}$ codifies for a protein that is homologous to shepherin II and includes a 26-amino acid putative signal peptide for secretion at its amino terminus. As previously demonstrated for the Capsella shepherins, the purified grapevine $\mathrm{PCr}$ protein displayed strong antibacterial activity against gram-negative bacteria $\left(\mathrm{IC}_{50} \leq 3 \mu \mathrm{g} / \mathrm{ml}\right)$ but it was also able to inhibit the growth of $B$. cinerea. Thus, $\mathrm{PCr}$ is not specifically active against $A$. mellea but it has a broad- 
spectrum antimicrobial activity and it is likely part of a more general defense response mounted by the root system following pathogen attack.

The other recombinant proteins did not show any inhibitory activity against $A$. mellea. In the absence of further analyses, we can hypothesize that these other SSH-identified proteins might be involved in more general plant reaction processes or they might be active against other pathogens. This could be the case for CYS1-inhibited B. cinerea growth, and the PIN1 and PIN2 proteins, which are commonly activated by necrotrophs (Aziz et al. 2007). It is also possible that these proteins are involved in broad-spectrum defense mechanisms, as observed for Pro-R, which is highly similar to the Pro-R protein VvPRP2 that is expressed in grapevine roots and probably acts at the cell wall (Thomas et al. 2003). Pro-R proteins are often involved in reinforcing or restructuring the cell wall. They do not have any direct inhibitory effect on the invading pathogen but they do help to limit its penetration (Josè and Puigdomènech 1993). A role for GLB in the defense process is less clear, because its sequence resembles those of leguminlike proteins that accumulate in maize endosperm (Hunter et al. 2002). Whereas our results indicate that grapevine $\mathrm{PCr}$ could play an important role in the roots' reaction against $A$. mellea, the general root response observed in our experiments seems to be nonspecific. These findings, together with the lack of reports describing Armillaria spp.-resistant Vitis genotypes, support the hypothesis that grapevine (as well as many other woody plants) has not acquired any specific resistance traits against this pathogen during the course of its evolution.

\section{MATERIALS AND METHODS}

Plant and fungal materials.

Rooted cuttings of the grapevine rootstock Kober 5BB ( $V$. berlandieri $\times V$. riparia) and $V$. vinifera $\mathrm{cv}$. Pinot Noir were grown for 2 months on 4-cm stone wool cubes (Grodan, Roermond, The Netherlands) under controlled greenhouse conditions at $20 \pm 3^{\circ} \mathrm{C}$ and $70 \pm 10 \%$ relative humidity. In vitro Kober 5BB plants were grown for 2 months in Magenta vessels (SigmaAldrich, St. Louis) on sterilized perlite with $20 \mathrm{ml}$ of $50 \%$ Murashige-Skoog (MS) salt liquid medium (Duchefa, Haarlem, The Netherlands) in a growth chamber kept at 23 and $18 \pm 1^{\circ} \mathrm{C}$ with a cycle of 16 and $8 \mathrm{~h}$, day and night, respectively. A. mellea 7A (SafeCrop collection), which was originally isolated from an infected grapevine in an Italian vineyard (Pertot et al. 2008), was grown for 4 weeks at $20^{\circ} \mathrm{C}$ in darkness on $3 \%$ malt extract agar (MEA) (Oxoid, Basingstoke, U.K.). To obtain a mycelial suspension (Weitz et al. 2002), small pieces (3 $\mathrm{mm}$ in diameter) of A. mellea mycelia were grown for 4 weeks at $20^{\circ} \mathrm{C}$ in darkness on malt extract broth (MEB) (Oxoid) at $120 \mathrm{rpm}$.

\section{Treatments of grapevine roots with $A$. mellea.}

For library construction, the root systems of two Kober 5BB plants were each sandwiched between two petri dishes containing confluent mycelia of an A. mellea colony (tester). As a control treatment, the root systems of two other plants were each sandwiched between two dishes containing uninoculated MEA (driver). The root systems were kept this way for $24 \mathrm{~h}$ at $20 \pm 2^{\circ} \mathrm{C}$.

For gene expression analyses, the roots of each Kober 5BB or Pinot Noir plant (grown either in the greenhouse or in vitro) were incubated for $24 \mathrm{~h}$ at $20^{\circ} \mathrm{C}$ with $20 \mathrm{~g}$ of A. mellea mycelia suspension that had been previously washed four times with sterilized $10 \mathrm{mM} \mathrm{MgCl}_{2}$. As control samples, the root systems of other plants were kept untreated or incubated in sterilized $10 \mathrm{mM} \mathrm{MgCl}$ solution for $24 \mathrm{~h}$ at $20^{\circ} \mathrm{C}$. In the greenhouse treatments, only the young roots that grew outside the stone wool cubes were treated, in order to avoid abiotic stress to the plants. For the in vitro experiments, Kober 5BB plants were transferred into new, sterilized vessels containing $20 \mathrm{ml}$ of fresh $50 \% \mathrm{MS}$. After 3 days, $10 \mathrm{ml}$ of the nutrient medium was removed and the roots were treated with $20 \mathrm{~g}$ of washed A. mellea mycelia or $20 \mathrm{ml}$ of $10 \mathrm{mM} \mathrm{MgCl}$ solution. One experiment consisted of three biological replicates (plants) for each treatment (untreated roots, $\mathrm{MgCl}_{2}$-treated, and $A$. mellea-treated at 24 or $96 \mathrm{~h}$ ). Each experiment performed in the different inoculation conditions (Kober 5BB greenhouse, Pinot noir greenhouse, and Kober $5 \mathrm{BB}$ in vitro) was carried out in three independent repetitions.

\section{Library construction by SSH.}

Root samples of the two replica plants were pooled together and total RNA was extracted from $4 \mathrm{~g}$ of A. mellea-treated (tester) and control (driver) roots using the hot borate method (Moser et al. 2004). Poly (A) ${ }^{+}$RNA was isolated using biotinilated oligo-dT (Promega Corp., Madison, WI, U.S.A.) and streptavidin-coupled magnetic M-280 dynabeads (Invitrogen, Carlsbad, CA, U.S.A.). Double-stranded cDNA was synthesized from $1 \mu \mathrm{g}$ of Poly $(\mathrm{A})^{+}$RNA using the Superscript Double-Stranded cDNA Synthesis Kit (Invitrogen). The forward subtracted library (enriched with A. mellea-induced cDNAs) was obtained by hybridizing the tester cDNA with an excess of driver cDNA using the PCR-Select cDNA Subtraction kit (Clontech, Mountain View, CA, U.S.A.) for SSH (Diatchenko et al. 1996). The resulting subtracted cDNA was cloned into the pCR2.1 TOPO vector (Invitrogen) and mobilized into $E$. coli TOP10 (Invitrogen). Positive transformants, based on blue/white color selection, were picked and grown in LuriaBertani (LB) broth (Sigma-Aldrich) supplemented with ampicillin at $100 \mathrm{mg} / \mathrm{liter}$ and $10 \%$ glycerol.

\section{SSH library colony screening.}

All positive clones of the SSH library were PCR amplified in a 384-well Geneamp 9700 Thermal Cycler (Applied Biosystems, Foster City, CA, U.S.A.) using nested primers (Clontech). After electrophoresis on agarose and ethidium bromide gels, the PCR products were spotted in duplicate on Amersham Hybond$\mathrm{N}^{+}$membranes (GE Healthcare, Piscataway, NJ, U.S.A.) with a 96-pin manual replicator system (V\&P Scientific, San Diego, CA, U.S.A.). Two different concentrations of insect nebulin cDNA were spotted as a control. Membranes were denatured (0.6 $\mathrm{M} \mathrm{NaOH}$ and $2 \mathrm{M} \mathrm{NaCl}$ ) and neutralized (0.6 M NaOH, $\mathrm{pH} 8.0$, and $2 \mathrm{M} \mathrm{NaCl}$ ) for $15 \mathrm{~min}$, and DNA was then crosslinked for $2 \mathrm{~h}$ at $80^{\circ} \mathrm{C}$. Digoxigenin (DIG)-labeled probes of tester, driver, forward (tester-driver), and reverse (driver-tester) cDNAs were generated using the PCR DIG Probe Synthesis Kit (Roche Diagnostics, Mannheim, Germany). Membranes were hybridized with $20 \mu \mathrm{l}$ of each of the DIG-labeled probes and denatured at $70^{\circ} \mathrm{C}$ for $10 \mathrm{~min}$, with $2 \mu \mathrm{l}$ of labeled nebulin in $20 \mathrm{ml}$ of hybridization buffer $(5 \times \mathrm{SSC}$ [ $1 \times \mathrm{SSC}$ is $0.15 \mathrm{M}$ $\mathrm{NaCl}$ plus $0.015 \mathrm{M}$ sodium citrate], $0.02 \%$ sodium dodecyl sulfate [SDS], $0.1 \% \mathrm{~N}$-lauroylsarcosine, and $1 \%$ blocking reagent) at $65^{\circ} \mathrm{C}$. After being washed twice with washing buffer $1(2 \times \mathrm{SSC}$ and $0.5 \% \mathrm{SDS})$ and twice with washing buffer $2(0.2 \times \mathrm{SSC}$ and $0.5 \% \mathrm{SDS})$ at $65^{\circ} \mathrm{C}$, the membranes were incubated in washing buffer 3 (malic acid buffer and $5 \%$ Tween-20), and then with the blocking solution (10\% blocking reagent in malic acid buffer). For detection, membranes were incubated in the antibody solution (1:20000 of anti-DIG-AP [Roche] in blocking solution) for $30 \mathrm{~min}$ and then washed twice with $100 \mathrm{ml}$ of washing buffer 3 . After equilibration in the detection buffer (1 M Tris- $\mathrm{HCl}, \mathrm{pH} 9.5$, and $1 \mathrm{M} \mathrm{NaCl}$ ), each membrane was covered with $1 \mathrm{ml}$ of CDP-STAR (Roche), a chemiluminescent substrate, and the signal was collected on 
Kodak film (Sigma-Aldrich). Clones showing the most marked differences in their expression as revealed by the hybridization results were selected for sequencing.

\section{Sequencing and sequence analysis.}

The selected clones were single-pass sequenced using the BigDye Terminator v3.1 cycle sequencing kit (Applied Biosystems), starting from $100 \mathrm{ng}$ of purified plasmid and 0.32 $\mu \mathrm{M}$ of nested primer 1 (Clontech). The cloned gene CDS were sequenced in both directions using the M13 forward and reverse primers (Invitrogen). Sequencing reactions were performed using a 2-min initial denaturation step, followed by 40 cycles of: $96^{\circ} \mathrm{C}$ for $10 \mathrm{~s}, 50^{\circ} \mathrm{C}$ for $5 \mathrm{~s}$, and $60^{\circ} \mathrm{C}$ for $4 \mathrm{~min}$. After ethanol precipitation, samples were resuspended and HI-DI formamide (Applied Biosystems) was added before sequencing via capillary electrophoresis in an ABI PRISM 3730xl DNA analyzer (Applied Biosystems). Following base-calling performed using Chromas software 2.33 (Technelysium Pty Ltd., Tewantin, Australia), low-quality sequences were discarded and vector and adaptor sequences were removed. The sequences were clustered into contigs using the CAP3 assembly program (Huang and Madan 1999) with a minimum overlap length of 40 nucleotides and $95 \%$ identity for overlaps.

For annotation, the sequences of contigs and singletons were aligned using blastn (Altschul et al. 1997) against the TIGR grapevine gene index database (version 6.0) and the predicted genes of the Pinot Noir genome sequence (release 3) (Velasco et al. 2007). Best hits with $E$ value $<10^{-5}$ were selected and annotated using blastx (Altschul et al. 1997) against the National Center for Biotechnology Information (NCBI) nonredundant protein database (July 2009). $E$ value scores below $10^{-10}$ were considered significant and were used to find the homologous sequences and to classify them into GO functional categories.

\section{Real-time RT-qPCR.}

Total RNA from the treated and control grapevine roots, as well as from A. mellea mycelia, was extracted using the Spectrum Plant total RNA kit (Sigma-Aldrich). RNA was quantified and treated with DNase I (Invitrogen), and the first-strand cDNA was synthesized from $1.0 \mu \mathrm{g}$ of total RNA using Superscript III (Invitrogen) and oligo-dT primer. The qPCR reactions were carried out with Platinum SYBR Green qPCR SuperMixUDG (Invitrogen), and specific primers (Table 2, each primer sequence finds only one significant match on the Pinot Noir genome sequence) using the ABI PRISM 7000 Sequence Detection System (Applied Biosystems). The qPCR conditions were $50^{\circ} \mathrm{C}$ for $2 \mathrm{~min}, 95^{\circ} \mathrm{C}$ for $2 \mathrm{~min}$ as initial steps, followed by 40 cycles of $95^{\circ} \mathrm{C}$ for $15 \mathrm{~s}$ and $60^{\circ} \mathrm{C}$ for $1 \mathrm{~min}$. Dissociation curves were analyzed to verify the specificity of each amplification reaction. ABI PRISM 7000 SDS software (Applied Biosystems) was used to extract cycle threshold values and LinReg software was used to calculate reaction efficiency (Ramakers et al. 2003). The relative expression of each gene was then calculated according to the Pfaffl (2001) equation, using untreated control roots as the calibrator and actin (TC100707) as the constitutive gene for normalization (Vandeleur et al. 2009), because its expression was not significantly affected by the treatments. For each treatment (untreated roots, $\mathrm{MgCl}_{2}$-treated, and A. mellea-treated at 24 or $96 \mathrm{~h}$ ), mean expression and standard error values were calculated on three biological replicates. The gene expression pattern was conserved in the three independent repetitions of the experiment.

\section{Fluorescent microscopy.}

Longitudinal sections ( $15 \mu \mathrm{m}$ thick) of grapevine roots were obtained using cryostat CM1510 (Leica, Wetzlar, Germany) and fungal hyphae were selectively stained using the FITC-
WGA method (Meyberg 1988). Root sections were immersed in $10 \% \mathrm{H}_{2} \mathrm{O}_{2}$ for $10 \mathrm{~min}$ and then incubated for $2 \mathrm{~h}$ in staining

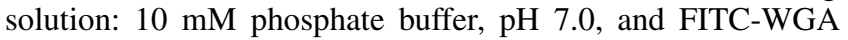
(Sigma-Aldrich) at $50 \mu \mathrm{g} /$ liter. The root sections were then washed in distilled water and images were taken using an Eclipse80i fluorescence microscope (Nikon Instruments EU, Amstelveen, The Netherlands) equipped with an FITC filter (EX 450-490, DM 505, BA 520) and a DS-Fi1 digital camera system (Nikon Instruments EU).

\section{5'-RACE RT-PCR.}

The full-length CDS of seven SSH-identified genes were obtained using the 5' RACE RT-PCR System (Invitrogen). First-strand cDNA was synthesized from the total RNA of $A$. mellea-treated Kober 5BB roots using the SuperScript II (Invitrogen) and specific reverse primers. After RNase Mix (Invitrogen) treatment, the cDNAs were purified using S.N.A.P. columns (Invitrogen) and a homopolymeric tail was added to their $3^{\prime}$ ends by using the terminal deoxynucleotidyl transferase (Invitrogen) with dCTP. CDS were then amplified using the specific reverse primers and the oligo-dG anchor primer (Invitrogen). The PCR fragments were purified using NucleoSpin Extract II (Macherey-Nagel, Düren, Germany), cloned into pCR2.1-TOPO (Invitrogen), and sequenced. We used ClustalW (Larkin et al. 2007) and Blast (Altschul et al. 1997) software to compare the recovered sequences with the original $\mathrm{SSH}$ sequences and to confirm the presence of the full length of each sequence. The sequence of CYS1 was amplified using specific primers designed based on TC89650 (TIGR Grape database v. 6.0), which is homologous to the strawberry gene Cyfl (Martinez et al. 2005).

\section{Expression and purification of the recombinant proteins.}

The presence of a putative signal peptide was detected using the SignalP v.3.0 program (Bendtsen et al. 2004). The sequences encoding for mature proteins were amplified using specific primers for subsequent cloning into the pET22b vector (Novagen, Madison, WI, U.S.A.) to achieve in-frame cytoplasmic expression of the peptides with the His tag. The amplified fragments were cloned into pCR2.1-TOPO (Invitrogen), sequenced, and introduced into pET22b (Novagen). The constructs were then mobilized into E. coli BL21 (Novagen).

Overexpressing bacterial cells were harvested by centrifugation, $20 \mathrm{~h}\left(5 \mathrm{~h}\right.$ for $\mathrm{PCr}$ ) following incubation at $28^{\circ} \mathrm{C}$ in $\mathrm{LB}$ broth (Sigma-Aldrich) supplemented with $1 \mathrm{mM}$ isopropyl- $\beta$ D-thiogalactoside. Cells were resuspended in four volumes of extraction buffer: $50 \mathrm{mM}$ phosphate buffer $(\mathrm{pH} 8.0)$, DNase (Sigma-Aldrich) at $50 \mu \mathrm{g} / \mathrm{ml}, 10 \mathrm{mM} \mathrm{MgCl}_{2}$, lysozyme (Sigma-Aldrich) at $500 \mu \mathrm{g} / \mathrm{ml}$, and $1 \times$ protease inhibitor cocktail (Sigma-Aldrich). Protein extracts were obtained following six cycles of sonication by Sonoplus HD 2070 (Bandelin, Berlin) and centrifugation at $20,000 \times g$ for $20 \mathrm{~min}$ at $4^{\circ} \mathrm{C}$. Imidazole and $\mathrm{NaCl}$ were then added to final concentrations of 10 and $300 \mathrm{mM}$, respectively, and recombinant proteins were purified by affinity chromatography in batch using the HIS-select nickel affinity gel (Sigma-Aldrich) with an elution buffer (50 mM phosphate buffer, $\mathrm{pH} 8.0,300 \mathrm{mM}$ imidazole, and 300 $\mathrm{mM} \mathrm{NaCl}$ ). Proteins were dialyzed in $10 \mathrm{mM}$ phosphate buffer, $\mathrm{pH}$ 6.5, concentrated using the Amicon Ultra 5K (Millipore, Billerica, MA, U.S.A.), sterilized by filtration (Millipore), quantified using Bradford reagent (Sigma-Aldrich), and analyzed by SDS polyacrylamide gel electrophoresis.

\section{Antimicrobial activity assays.}

Small fragments ( $1 \mathrm{~mm}$ in diameter) of fresh A. mellea mycelia were incubated for $72 \mathrm{~h}$ at $20^{\circ} \mathrm{C}$ under sterile conditions, in the presence of different concentrations $(0$ to $500 \mu \mathrm{M})$ of 
purified proteins. Six replicates of approximately $150 \mathrm{~A}$. mellea fragments each were exposed to each protein concentration in a final volume of $200 \mu \mathrm{l}$ in $10 \mathrm{mM}$ phosphate buffer ( $\mathrm{pH} \mathrm{6.5)}$. The $A$. mellea fragments were plated onto potato dextrose agar (PDA) (Oxoid) and the percentage of live A. mellea fragments (which produced white mycelia) on each plate was evaluated after 3 days of incubation at $20^{\circ} \mathrm{C}$. The inhibition activity was calculated as a percentage of the growth of A. mellea in the presence of the control treatment, which was $10 \mathrm{mM}$ phosphate buffer ( $\mathrm{pH}$ 6.5).

Activity against $B$. cinerea was analyzed following the mycelial growth inhibition assay described by Goñi and associates (2009). Briefly, fresh B. cinerea mycelia were plated onto PDA and, following $24 \mathrm{~h}$ of incubation at $25^{\circ} \mathrm{C}$, sterile filter paper discs ( $5 \mathrm{~mm}$ in diameter), with $30 \mu \mathrm{l}$ of $200 \mu \mathrm{g}$ of purified proteins in $10 \mathrm{mM}$ phosphate buffer $(\mathrm{pH}$ 6.5) placed in front of the advancing fungal mycelium. As negative control, the same amount of bovine serum albumin (Sigma-Aldrich) was spotted. The assays were conducted in triplicate and inhibition zones were evaluated following $24 \mathrm{~h}$ of incubation at $25^{\circ} \mathrm{C}$.

Activity against the bacteria $E$. coli TOP10 (Invitrogen) and Pseudomonas fluorescens WCS417r was determined as described by Park and associates (2000). Bacterial cells of the mid-exponential phase culture were centrifuged at $5,000 \times g$ for $10 \mathrm{~min}$ at $4^{\circ} \mathrm{C}$, then washed three times with cold $10 \mathrm{mM}$ phosphate buffer ( $\mathrm{pH}$ 6.5). The concentration of the bacterial suspension was measured using a Burker chamber under a light microscope, and 200- $\mu \mathrm{l}$ aliquots of $10^{3} \mathrm{CFU} / \mathrm{ml}$ were incubated for $2 \mathrm{~h}$ at room temperature in the presence of different concentrations ( 0 to $6.3 \mu \mathrm{M})$ of the recombinant proteins, in six replicates. Suspensions were plated onto LB agar (Sigma-Aldrich) and the numbers of colonies were determined following $24 \mathrm{~h}$ of incubation at $37^{\circ} \mathrm{C}$ for E. coli or $28^{\circ} \mathrm{C}$ for $P$. fluorescens. The protein concentration required for a $50 \%$ reduction in the number of CFU relative to that of the control corresponds to the $\mathrm{IC}_{50}$ value.

All experiments were repeated at least three times with similar results. Analysis of variance of the data was conducted using the Statistica 7.1 software (StatSoft, Tulsa, OK, U.S.A.) following validation of normal distribution of the data, to demonstrate insignificant treatment-experiment interactions $(P>0.05)$, and to compare the means of antimicrobial activity (Tukey's test).

\section{ACKNOWLEDGMENTS}

The research was supported by SafeCrop Centre, a project funded by the Autonomous Province of Trento, and by the Advanced Biology Project, which was funded by the Fondazione delle Casse di Risparmio di Trento e Rovereto. Protein purification and antifungal experiments were supported by the Post-Doc Project 2006 Resistevite, funded by the Autonomous Province of Trento. We thank C. M. J. Pieterse for the kind gift of the strain WCS417r of Pseudomonas fluorescens, F. Schwarz for help in setting up the infection experiments, and C. Segala for bioinformatic support.

\section{LITERATURE CITED}

Aguín-Casal, O., Sainz-Oses, M. J., and Mansilla-Vazquez, J. P. 2004. Armillaria species infesting vineyards in northwestern Spain. Eur. J. Plant Pathol. 110:683-687.

Aguín-Casal, O., Mansilla-Vazquez, J. P., and Sainz-Oses, M. J. 2006. In vitro selection of an effective fungicide against Armillaria mellea and control of white root rot of grapevine in the field. Pest Manage. Sci. 62:223-228

Altschul, S. F., Madden, T. L., Schaffer, A. A., Zhang, J., Zhang, Z., Miller, W., and Lipman, D. J. 1997. Gapped BLAST and PSI-BLAST: A new generation of protein database search programs. Nucleic Acid Res. 25:3389-3402.

Apel, K., and Hirt, H. 2004. Reactive oxygen species: Metabolism, oxidative stress, and signal transduction. Annu. Rev. Plant Biol. 55:373-399.
Aziz, A., Gauthier, A., Bézier, A., Poinssot, B., Joubert, J. M., Pugin, A. Heyraud, A., and Baillieul, F. 2007. Elicitor and resistance-inducing activities of beta-1,4 cellodextrins in grapevine, comparison with beta-1,3 glucans and alpha-1,4 oligogalacturonides. J. Exp. Bot. 58:1463-1472.

Baumgartner, K. 2004. Root collar excavation for postinfection control of Armillaria root disease of grapevine. Plant Dis. 88:1235-1240.

Baumgartner, K., and Rizzo, D. M. 2002. Spread of Armillaria root disease in a California vineyard. Am. J. Enol. Vitic. 53:197-203.

Baumgartner, K., and Rizzo, D. M. 2006. Relative resistance of grapevine rootstocks to Armillaria root disease. Am. J. Enol. Vitic. 57:408-414.

Baumgartner, K., and Warnock, A. E. 2006. A soil inoculant inhibits $A r$ millaria mellea in vitro and improves productivity of grapevines with root disease. Plant Dis. 90:439-444.

Belhadj, A., Telef, N., Saigne, C., Cluzet, S., Barrieu, F., Hamdi, S., and Mérillon, J. M. 2008. Effect of methyl jasmonate in combination with carbohydrates on gene expression of PR proteins, stilbene and anthocyanin accumulation in grapevine cell cultures. Plant Physiol. Biochem. 46:493-499.

Bendel, M., Kienast, F., and Rigling, D. 2006. Genetic population structure of three Armillaria species at the landscape scale: A case study from Swiss Pinus mugo forests. Mycol. Res. 110:705-712.

Bendtsen, J. D., Nielsen, H., von Heijne, G., and Brunak, S. 2004. Improved prediction of signal peptide: SignalP 3.0. J. Mol. Biol. 340:783795.

Brenner, E. D., Lambert, K. N., Kaloshian, I., and Williamson, V. M. 1998. Characterization of LeMir, a root-knot nematode-induced gene in tomato with an encoded product secreted from the root. Plant Physiol. 118:237-247.

Camprubí, A., Estaún, V., Nogales, A., García-Figueres, F., Pitet, M., and Calvet, C. 2008. Response of the grapevine rootstock Richter 110 to inoculation with native and selected arbuscular mycorrhizal fungi and growth performance in a replant vineyard. Mycorrhiza 18:211-216.

Coetzee, M. P., Wingfield, B. D., Bloomer, P., and Wingfield, M. J. 2005. Phylogenetic analyses of DNA sequences reveal species partitions amongst isolates of Armillaria from Africa. Mycol. Res. 109:12231234

Cox, K. D., and Scherm, H. 2006. Interaction dynamics between saprobic lignicolous fungi and Armillaria in controlled environments: Exploring the potential for competitive exclusion of Armillaria on peach. Biol. Control 37:291-300.

Diatchenko, L., Lau, Y. F., Campbell, A. P., Chenchik, A., Moqadam, F., Huang, B., Lukyanov, S., and Siebert, P. D. 1996. Suppression subtractive hybridization: A method for generating differentially regulated or tissue-specific cDNA probes and libraries Proc. Natl. Acad. Sci. U.S.A. 93:6025-6030.

Eulgem, T. 2005. Regulation of the Arabidopsis defense transcriptome. Trends Plant Sci. 10:71-78.

Figueiredo, A., Fortes, A. M., Ferreira, S., Sebastiana, M., Choi, Y. H., Sousa, L., Acioli-Santos, B., Pessoa, F., Verpoorte, R., and Pais, M. S. 2008. Transcriptional and metabolic profiling of grape (Vitis vinifera L.) leaves unravel possible innate resistance against pathogenic fungi. J. Exp. Bot. 59:3371-3381.

Fox, R. T. V. 2000. Armillaria Root Rot: Biology and Control of Honey Fungus. Intercept, Andover, UK.

Fox, R. T. V. 2003. Managing Armillaria root rot. Food Agric. Environ. 1:95-100

Gatto, P., Vrhovsek, U., Muth, J., Segala, C., Romualdi, C., Fontana, P., Pruefer, D., Stefanini, M., Moser, C., Mattivi, F., and Velasco, R. 2008. Ripening and genotype control stilbene accumulation in healthy grapes. J. Agric. Food Chem. 56:11773-11785.

Goñi, O., Sanchez-Ballesta, M.T., Merodio, C., and Escribano, M. I. 2009. Regulation of defense and cryoprotective proteins by high levels of $\mathrm{CO}_{2}$ in Annona fruit stored at chilling temperature. J. Plant Physiol. $166: 246-258$.

Hamiduzzaman, M. M., Jakab, G., Barnavon, L., Neuhaus, J. M., and Mauch-Mani, B. 2005. beta-aminobutyric acid-induced resistance against downy mildew in grapevine acts through the potentiation of callose formation and jasmonic acid signaling. Mol. Plant-Microbe Interact. 18:819-829.

Huang, X., and Madan, A. 1999. CAP3: A DNA sequence assembly program. Genome Res. 9:868-877.

Hunter, B. G., Beatty, M. K., Singletary, G. W., Hamaker, B. R., Dilkes, B. P., Larkins, B. A., and Jung R. 2002. Maize opaque endosperm mutations create extensive changes in patterns of gene expression. Plant Cell 14:2591-2612.

Isidorov, V. A., Lech, P., Źółciak, A., Rusak, M., and Szczepaniak, L. 2008. Gas chromatographic-mass spectrometric investigation of metabolites from the needles and roots of pine seedlings at early stages of pathogenic fungi Armillaria ostoyae attack. Trees (Berl.) 22:531-542.

Jacobs, A. K., Dry, I. B., and Robinson, S. P. 1999. Induction of different 
pathogenesis-related cDNAs in grapevine infected with powdery mildew and treated with ethephon. Plant Pathol. 48:325-336.

Jayasankar, S., Li, Z., and Gray, D. J. 2003. Constitutive expression of Vitis vinifera thaumatin-like protein after in vitro selection and its role in anthracnose resistance. Funct. Plant Biol. 30:1105-1115.

Josè , M, and Puigdomènech, P. 1993. Structure and expression of genes coding for structural proteins of plant cell wall. New Phytol. 125:259-282

Karrer, E. E., Beachy, R. N., and Holt, C. A. 1998. Cloning of tobacco genes that elicit the hypersensitive response. Plant Mol. Biol. 36:681690

Kortekamp, A. 2006. Expression analysis of defence-related genes in grapevine leaves after inoculation with a host and a non-host pathogen. Plant Physiol. Biochem. 44:58-67.

Lamb, C., and Dixon, R. A. 1997. The oxidative burst in plant disease resistance. Annu. Rev. Plant Physiol. Plant Mol. Biol. 48:251-275.

Larkin, M. A., Blackshields, G., Brown, N. P., Chenna, R., McGettigan, P. A., McWilliam, H., Valentin, F., Wallace, I. M., Wilm, A., Lopez, R., Thompson, J. D., Gibson, T. J., and Higgins, D. G. 2007. ClustalW and ClustalX version 2. Bioinformatics 23:2947-2948.

Lee, S. C., Hwang, I. S., Choi, H. W., and Hwang, B. K. 2008. Involvement of the pepper antimicrobial protein CaAMP1 gene in broad spectrum disease resistance. Plant Physiol. 148:1004-1020.

Martinez, M., Abraham, Z., Gambardella, M., Echaide, M., Carbonero, P., and Diaz, I. 2005. The strawberry gene Cyf 1 encodes a phytocystatin with antifungal properties. J. Exp. Bot. 56:1821-1829.

Meyberg, M. 1988. Selective staining of fungal hyphae in parasitic and symbiotic plant-fungus associations. Histochemistry 88:197-199.

Monteiro, S., Barakat, M., Piçarra-Pereira, M. A., Teixeira, A. R., and Ferreira, R. B. 2003. Osmotin and thaumatin from grape: A putative general defense mechanism against pathogenic fungi. Phytopathology 93:1505-1512.

Moser, C., Gatto, P., Moser, M., Pindo, M., and Velasco, R. 2004. Isolation of functional RNA from small amounts of different grape and apple tissues. Mol. Biotechnol. 26:95-100.

Mwenje, E., Wingfield, B. D., Coetzee, M. P. A., Nemato, H., and Wingfield, M. J. 2006. Armillaria species on tea in Kenya identified using isozyme and DNA sequence comparisons. Plant Pathol. 55:343-350.

Nogales, A., Aguirreolea, J., María, E. S., Camprubí, A., and Calvet, C. 2008. Response of mycorrhizal grapevine to Armillaria mellea inoculation: Disease development and polyamines. Plant Soil 317:177-187.

Otieno, W., Termorshuizen, A., Jeger, M., and Othieno C.O. 2003. Efficacy of soil solarization, Trichoderma harzianum, and coffee pulp amendment against Armillaria spp. Crop Prot. 22:325-331.

Park, C. J., Park, C. B., Hong, S. S., Lee, H. S., Lee, S. Y., and Kim, S. C. 2000. Characterization and cDNA cloning of two glycine- and histidine-rich antimicrobial peptides from the roots of shepherd's purse, Capsella bursa-pastoris. Plant Mol. Biol. 44:187-197.

Pertot, I., Gobbin, D., De Luca, F., and Prodorutti, D. 2008. Methods of assessing the incidence of Armillaria root rot across viticultural areas and the pathogen's genetic diversity and spatial-temporal pattern in northern Italy. Crop Prot. 27:1061-1070.

Pfaffl, M. W. 2001. A new mathematical model for relative quantification in real-time RT-PCR. Nucleic Acid Res. 29:e45.

Pieterse, C. M. J., Leon-Reyes, A., van der Ent, S., and van Wees, S. C. M. 2009. Networking by small-molecule hormones in plant immunity. Nat. Chem. Biol. 5:308-316

Prodorutti, D. De Luca, F., Michelon, L., and Pertot, I. 2009. Susceptibility to Armillaria mellea root rot of grapevine rootstocks commonly grafted onto Teroldego Rotaliano. Phytopathol. Mediterr. 48:285-290.

Prospero, S., Lung-Escarmant, B., and Dutech, C. 2008. Genetic structure of an expanding Armillaria root rot fungus (Armillaria ostoyae) popula- tion in a managed pine forest in southwestern France. Mol. Ecol. 17:3366-3378.

Ramakers, C., Ruijter, J. M., Deprez, R. H., and Moorman, A. F. 2003. Assumption-free analysis of quantitative real-time polymerase chain reaction (PCR) data. Neurosci. Lett. 339:62-66.

Robinson, R. M., Sturrock, R. N., Davidson, J. J., Ekramoddoullah, A. K., and Morrison, D. J. 2000. Detection of a chitinase-like protein in the roots of Douglas-fir trees infected with Armillaria ostoyae and Phellinus weirii. Tree Physiol. 20:493-502.

Sels, J., Mathys, J., De Coninck, B. M., Cammue, B. P., and De Bolle, M. F. 2008. Plant pathogenesis-related (PR) proteins: A focus on PR peptides. Plant Physiol. Biochem. 46:941-950.

Shetty, N. P., Jorgensen, H. J. L., Jensen, J. D., Collinge, D. B., and Shetty, H. S. 2008. Roles of reactive oxygen species in interactions between plants and pathogens. Eur. J. Plant Pathol. 121:267-280.

Thomas, P., Lee, M. M., and Schiefelbein, J. 2003. Molecular identification of proline-rich protein genes induced during root formation in grape (Vitis vinifera L.) stem cuttings. Plant Cell. Environ. 26:14971504

Tsukuda, S., Gomi, K., Yamamoto, H., and Akimitsu, K. 2006. Characterization of cDNAs encoding two distinct miraculin-like proteins and stress-related modulation of the corresponding mRNAs in Citrus jambhiri lush. Plant Mol Biol. 60:125-136.

Vandeleur, R. K., Mayo, G., Shelden, M. C., Gilliham, M., Kaiser, B. N., and Tyerman, S. D. 2009. The role of plasma membrane intrinsic protein aquaporins in water transport through roots: Diurnal and drought stress responses reveal different strategies between isohydric and anisohydric cultivars of grapevine. Plant Physiol. 149:445-460.

van Loon, L. C., Geraats, B. P., and Linthorst, H. J. 2006. Ethylene as a modulator of disease resistance in plants. Trends Plant Sci. 11:184-191.

van Wees, S. C. M., Luijendijk, M., Smoorenburg, I., van Loon, L. C., and Pieterse, C. M. J. 1999. Rhizobacteria-mediated induced systemic resistance (ISR) in Arabidopsis is not associated with a direct effect on expression of known defense-related genes but stimulates the expression of the jasmonate-inducible gene Atvsp upon challenge. Plant Mol. Biol. 41:537-549.

Velasco, R., Zharkikh, A., Troggio, M., Cartwright, D.A., Cestaro, A., et al. 2007. A high quality draft consensus sequence of the genome of a heterozygous grapevine variety. PLoS ONE 2:e1326.

Vítecek, J., Kasparovský, T., Mikesová, M., and Mikes, V. 2005. Nonspecific elicitation of defense reaction in suspension tobacco cells by elicitors from Armillaria. Folia Microbiol. (Prague) 50:128-132.

Wang, H. X., Yang, T., Zeng, Y., and Hu, Z. 2007. Expression analysis of the gastrodianin gene ga4B in an achlorophyllous plant Gastrodia elata B1. Plant Cell Rep. 26:253-259.

Weitz, H. J., Campbell, C. D., and Killham, K. 2002. Development of a novel, bioluminescence-based, fungal bioassay for toxicity testing. Environ. Microbiol. 4:422-429.

\section{AUTHOR-RECOMMENDED INTERNET RESOURCES}

BLAST search page:

genomics.research.iasma.it/iasma/faces/BlastPage.jsp

ExPASy Proteomics server: www.expasy.ch

The Gene Index project grape gene index website: compbio.dfci.harvard.edu/tgi/cgi-bin/tgi/gimain.pl?gudb=grape

Gene Ontology website: www.geneontology.org

NCBI home page: www.ncbi.nlm.nih.gov

NCBI nonredundant BLAST database: blast.ncbi.nlm.nih.gov/Blast.cgi

SignalP v.3.0 server: www.cbs.dtu.dk/services/SignalP 